\title{
An Economic Analysis of Marketing of Onion (allium cepa) in Mahabubnagar District of Telangana
}

\author{
Munasu Vikas ${ }^{1 *}$, Dr. Ramchandra ${ }^{2}$ \\ Department of Agriculture Economics, \\ Sam Higginbottom University of Agriculture Technology and sciences \\ Prayagraj-211007, Uttar Pradesh,
}

\begin{abstract}
The study is an analysis of price spread, producer's share in consumer's rupee and marketing efficiency of onion in Telangana state. The study was carried out in Mahabubnagar district of the state. A multistage sampling technique was employed to select the market functionaries from whom information were collected using structural questionnaires from the different marketing channels. Channel -1 Producer consumer, Channel -2 Producer - village merchant/ Retailer - consumer, Channel -3 Producer- WholesaerRetailer/village merchant- consumer. Then the data is analyzed using tabulation method along with statistical tool.
\end{abstract}

Keywords:- Onion, Price Spread, Producer's Share in Consumers Rupee, Marketing Efficiency.

\section{INTRODUCTION}

Onion belongs to the family Alliaceae ,origin asia. It is one of the most important commercial vegetable crop grown by large, small, and medium farmers in different parts of the country, Onion is the important vegetable crop widely used in all households all the year round. Onions are good source of dietary fiber, folic acid and contain calcium, iron, high protein quality and medicinal values. India is the second largest producer of onion in the world. Indian onions are famous for their pungency. Onion is mostly consumed vegetable crop in India. Maharashtra alone produces 70 percent of onions in the country.

\section{RESEARCH METHODOLOGY}

The study was conducted in Mahabubnagar district of Telangana which is one of the 31 districts of Telangana. Mahabubnagar district comprises of 64 blocks among 2 blocks were selected i.e Gadwal and waddepalle blocks were selected for the study. Out of this villages, waddepale was seleted for primary market and gadwall was selected was selected as secondary market purposively for the present study. All market functionaries of both Primary and secondary market is prepared with the help of market head out of total market functionaries $10 \%$ market functionaries selected randomly from both market for present study this market functionaries will be considered for data collection regarding different marketing cost and other charges in different marketing channels. Price spread, producers share in consumer's rupee and marketing efficiency were calculated using required formula.

\section{RESULTS AND DISCUSSIONS}

The study was conducted in Mahabubnagar district of Telangana. The necessary data were collected from the market functionaries in above mentioned district. The present chapter is going to tell about the results and discussions for various objectives. The chapter is arranged in different sub-sections according to objectives of the study.

$>$ To workout Price spread, Producer's share in consumer's rupee and Marketing efficiency in different existing channels.

* Marketing Channels:

There are three marketing channels for the onion marketing in Mahabubnagar district given below.

- Channel-I Producer-consumer

- Channel - II Producer- village merchant/ retailerconsumer.

- Channel - III Producer - Wholesaler- retailer/village merchant-consumer. 


\begin{tabular}{|c|c|c|c|c|}
\hline $\begin{array}{c}\text { S. } \\
\text { No }\end{array}$ & Particulars & Channel - I & Channel - II & Channel - III \\
\hline 1 & Producer sale price to consumer & 900 & 900 & \\
\hline 2 & Cost incurred by the producer & & & \\
\hline I. & Transportation cost & 20 & 20 & \\
\hline II. & Packing cost & 15 & 15 & \\
\hline III. & Packing material cost & 20 & 20 & \\
\hline IV. & Loading and unloading charges & 30 & 30 & \\
\hline $\mathrm{V}$. & Miscellaneous charges & 20 & 20 & \\
\hline VI. & Weighing charges & 10 & 10 & \\
\hline 3 & Total marketing cost $(\mathrm{i}-\mathrm{vi})$ & 115 & 115 & \\
\hline 4 & Net price received by producer & 785 & 785 & \\
\hline 5 & Sale price of producer to consumer & $900(100)$ & & \\
\hline 6 & Consumer paid price & 900 & & \\
\hline 7 & Price spread & 115 & & \\
\hline 8 & Producer share in consumer rupee $(\%)$ & 87.2 & & \\
\hline 9 & Marketing efficiency & 7.82 & & \\
\hline 10 & Sale price of producer the village merchant/retailer & & 1015 & \\
\hline 11 & Cost incurred by the village merchant & & & \\
\hline I. & Transportation cost & & 20 & \\
\hline II. & Packing cost & & 15 & \\
\hline III. & Packing material cost & & 20 & \\
\hline IV. & Loading and unloading cost & & 30 & \\
\hline $\mathrm{V}$. & Miscellaneous charges & & 20 & \\
\hline VI. & Weighing charges & & 20 & \\
\hline VII. & Margin of village merchant/retailer & & 200 & \\
\hline 11 & Total marketing cost $(\mathrm{i}-\mathrm{vi})$ & & 325 & \\
\hline 12 & Sale price of village merchant/ retailer & & $1340(100)$ & \\
\hline 13 & Price spread & & 440 & \\
\hline 14 & Consumer paid price & & 1340 & \\
\hline 15 & Producer share in consumer rupee $(\%)$ & & 58.58 & \\
\hline 16 & Marketing efficiency & & 3.04 & \\
\hline 17 & Producer sale price to wholesaler & & & 1015 \\
\hline 18 & Cost incurred by the wholesaler & & & \\
\hline I. & Loading and un loading charges & & & 40 \\
\hline II. & Packing cost & & & 45 \\
\hline III. & Market fee & & & 25 \\
\hline IV. & Commission of wholesaler & & & 100 \\
\hline $\mathrm{V}$. & Miscellaneous charges & & & 20 \\
\hline VI. & Margin of wholesaler/commission agent & & & 300 \\
\hline 19 & Total cost & & & 530 \\
\hline 20 & Sale price of wholesaler to retailer & & & 1545 \\
\hline 21 & Cost incurred by retailer retailer/village merchant & & & \\
\hline I. & Weighing charges & & & 70 \\
\hline II. & Loading and un loading charges & & & 45 \\
\hline III. & Town charges & & & 80 \\
\hline IV. & Carrying up to shop & & & 15 \\
\hline $\mathrm{V}$. & Miscellaneous charges & & & 60 \\
\hline VI. & Margin of retailer/ village merchant & & & 250 \\
\hline 22 & Total cost & & & 520 \\
\hline 23 & Sale price of retailer/ village merchant to consumer & & & $2065(100)$ \\
\hline 24 & $\begin{array}{c}\text { Price spread } \\
\end{array}$ & & & 1165 \\
\hline 25 & Consumers paid price & & & 2065 \\
\hline 26 & Producer share in consumer rupee $(\%)$ & & & 38.01 \\
\hline 27 & Marketing efficiency & & & 1.77 \\
\hline
\end{tabular}

Table 1:- sample average for three different existing marketing channels 
Table 1 reveals that in channel - I sample average marketing cost for small, medium and large size farm groups when producer sold their product directly to consumers in the local market ,consumer Rupee was 87.2 percent. price spread is Rs.115. marketing efficiency was 7.82 Percent.

In channel - II that marketing cost, marketing margin, and price spread for channel II. One intermediaries were identified through which Onion reaches to the consumer's i,e. Village merchant/ Retailer. This is the channel among two identified channel. The producer sells his produce to the Village merchant/ Retailer, and Village merchant/ Retailer, who in turn sell it to the consumers in the market. Finally the produce reaches to consumers after collecting margin.

Marketing cost when producers sold their produce to Village merchant/ Retailer, was Rs.115/quintal. Among these cost transportation charges was most important which accounted for Rs.15/quintal, followed by loading and unloading cost Rs.20/quintal, and miscellaneous cost Rs.20/quintal respectively. Sale price of the producer to Village merchant/ Retailer was -Rs.1015/quintals in different farms size group. In these channel marketing cost of the village merchant/retailer Rs.325/quintals. Among this costs of transportation was so important which accounts for , followed by loaded and unloading charges Rs.30 ,carrying weighing charges Rs.20, and miscellaneous charges Rs.20, Producer share in consumer price was estimated to be 58.58 per cent. Price spread was estimated to be Rs. 440/quintal of consumer paid price. Marketing efficiency was 3.04 per cent.
In Channel-III the marketing cost, marketing margin, and price spread for channel III. Three intermediaries were identified through which onion reaches to the consumer's i.e. wholesaler and Retailer/village merchant. This is the longest channel among two identified channels. The producer sells his produce to the wholesaler, wholesaler to retailer/ village merchant. Finally the produce reaches to consumers after collecting margin. Marketing cost when producers sold their produce to wholesaler, was Rs.115/quintal. Among these cost transportation charges was most important which accounted for Rs.15/quintal, followed by loading and unloading cost Rs.20/quintal, and miscellaneous cost Rs.20/quintal respectively. Average marketing cost when wholesaler sold their produce to retailer/ village merchant was Rs.530 /quintal. Among these cost packing cost was most important which accounted for Rs. 45/quintal, followed by loading and unloading cost Rs. 40/quintal, market fee Rs. 25/quintal, and miscellaneous charges Rs.20/quintal, respectively. The sample average market cost for retailer/village merchant sold their products to consumer was Rs.520/quintal. Among these cost Town charges was most important which accounted for Rs. 70/quintal, followed by loading and unloading cost Rs. 45/quintal and miscellaneous charges Rs.60/quintal, respectively. The marketing margin of retailer/ village merchant was estimated to be 12.10 per cent and commission of wholesaler marketing margin was 14.52 per cent of the consumer paid price. Producer share in consumer price was (38.01 per cent). Price spread was Rs.1165 /quintal of consumer paid price. Market efficiency was 1.77 per cent.

\begin{tabular}{|c|c|c|c|c|}
\hline S. No & Particulars & Channel I & Channel II & Channel III \\
\hline 1 & Total marketing cost & 115 & 240 & 615 \\
\hline 2 & Total marketing margin & 0 & 200 & 550 \\
\hline 3 & Price spread & 115 & 440 & 1165 \\
\hline 4 & Producer share in consumer rupee (\%) & 87.2 & 58.58 & 38.01 \\
\hline 5 & Marketing efficiency & 7.82 & 3.04 & 1.77 \\
\hline
\end{tabular}

Table 2:- Comparison of total marketing cost, total marketing margin, price spread, producer share in consumer rupee(\%) and marketing efficiency in three different channels:

Table 2 reveals that total marketing cost in channel-I was Rs.115/quintal, price spread Rs.115/quintal, producer share in consumer rupee 87.2, marketing efficiency 7.82 percentage and there is no total marketing margin respectively. The total marketing cost in channel-II was Rs.240/quintal, total marketing margin Rs.200/quintal, price spread Rs.440/quintal, producer share in consumer rupee 58.58and marketing efficiency 3.034percentage.The total marketing cost in channel-III was Rs.615/quintal, followed by total marketing margin Rs.550/quintal, price spread Rs.1165/quintal, producer share in consumer rupee 38.01 and marketing efficiency 1.77 percentage.

\begin{tabular}{|c|c|c|c|c|c|c|c|c|}
\hline Source & $\boldsymbol{d} \boldsymbol{f}$ & $\boldsymbol{S . S}$ & $\boldsymbol{M S S}$ & F. Cal & F. Tab 5\% & Result & S. Ed & C.D at 5\% \\
\hline channel & 2 & 440058.6 & 220029.3 & 4.09 & 4.45897 & NS & 189.19 & 435.137 \\
\hline Particular & 4 & 617009.3 & 154252.34 & 2.87 & 3.837853 & NS & 146.54 & 337.042 \\
\hline Error & 8 & 429515.64 & 53689.4 & & & & & \\
\hline Total & 14 & & & & & & \\
\hline
\end{tabular}

Table 3:- Anova 
In the above Anova table, in due to size group degrees of freedom is 2, sum of squares is 440058.6, mean sum of squares is 220029.3 , F. Calculated value is 4.09 , F. tabulated value @ 5\% is 4.45, result is not significant, standard deviation is 189.19 and critical difference is @ 5\% is 435.137. In due to particulars, degrees of freedom is 2 , sum of squares is 617009.3 .7 , mean sum of squares is 154252.34 , F. Calculated value is 2.87, F. tabulated value @ 5\% is 3.837853 , result is not significant, standard deviation is 146.54 and critical difference is 337.042. In error, degree of freedom is 4 , sum of squares is 429515.64 and mean sum of squares in error is 53689.4.

\section{CONCLUSION}

Among the three marketing channels identified in Mahabubnagar regulated market district, the channel -III, i.e Producer - wholesaler- retailer-consumer was found more popular in marketing of onion, The prices of onions have not influenced by the arrivals in Mahabubnagar market. The maximum Prices of tapioca were observed during the month of January. Thus, the sellers prefer these months for selling of onion in Mahabubnagar Market.

\section{REFERENCES}

[1]. Gessesse A. Analysis of fruit and vegetable market chains in Alamata, southern zone of Tigray: the case of onion, tomato and papaya. M.Sc. Thesis, Haramaya University, Ethiopia, 2009, 55-59.

[2]. Gadge, S.S. and Lawande, 2012. Crop damage due to climatic change: A major Constraint in onion farming, Indian Research Journal of Extension Education Special Issue, Vol. II.

[3]. Ghulghule; J.N. and Thomore A.P., 2009. Profitability of Kharif onion (Allium cepa Linn) production, The Asian Journal of Horticulture, 4(1): 8688.

[4]. Kodge vasant Baburao, 2013. Onion marketing in India: A case study of Maharashtra, Research Matrix International Journal, Vol-1.

[5]. Reddy, B.S., Dikshit, A.K., Chandrashekhar, S.M. and Manohar N.S., 2012. Price trend and integration of wholesale Market of onion in metro cities of India, Journal of Economics and Sustainable Development, 3(7): 2222-2855. 